\title{
Teaching NeuroImages: Aspergillosis-induced vasculitis presenting as ischemic stroke in an immunocompetent patient
}

David Lebeaux, MD, PhD, Isabelle Klein, MD, PhD, Gabriel Garcia, MD, Fabrice Bruneel, MD, Fernando Pico, MD, PhD, and Olivier Lortholary, MD, PhD

Neurology ${ }^{\circledR}$ 2019;92:e2618-e2619. doi:10.1212/WNL.0000000000007575
Correspondence

Dr. Lebeaux

david.lebeaux@aphp.fr

Figure Acute ischemia secondary to internal carotid stenosis caused by a perivascular infiltrative enhancing mass

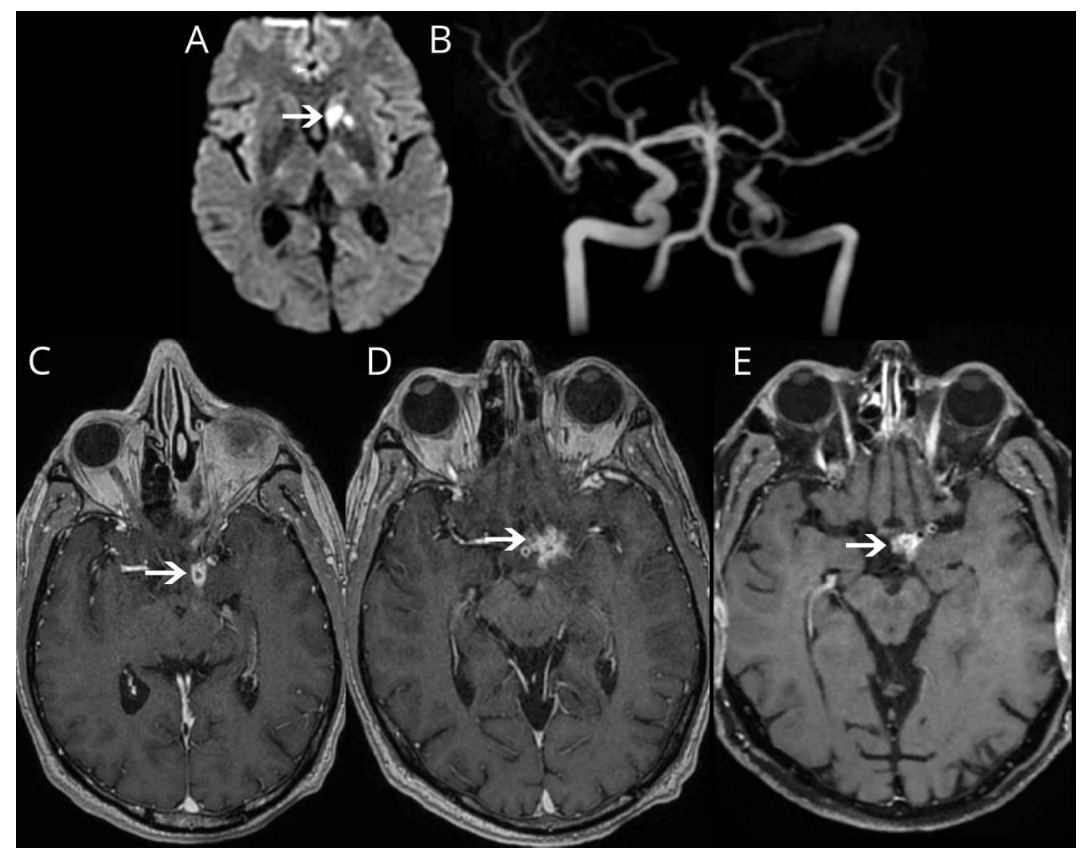

(A) Acute ischemia on diffusion-weighted imaging in the left lentiform and caudate nucleus. (B) Time-of-flight magnetic resonance angiography: high-grade stenosis of the internal carotid with subsequent low flow. (C-E) Postcontrast T1-weighted MRI: perivascular infiltrative enhancing mass (C) at diagnosis and after (D) 7 and (E) 15 months of therapy.

A 56-year-old immunocompetent man had surgery for pansinusitis; culture grew Aspergillus fumigatus. Two months later, he suddenly experienced febrile right-sided hemiplegia. Brain MRI revealed a recent infarction of the left lentiform and caudate nucleus (figure, A) with left internal carotid and middle cerebral arteries stenosis (figure, B) caused by a perivascular infiltrative mass (figure, $\mathrm{C}$ ). CSF analysis revealed lymphocytic meningitis and $\beta$-D-glucans levels of $190 \mathrm{pg} / \mathrm{mL}$ (negative in serum). MRI worsened despite voriconazole followed by voriconazole/caspofungin (figure, D) but improved with caspofungin and liposomal amphotericin B during 15 months (figure, E). Cerebral aspergillosis-related vasculitis has been rarely reported. ${ }^{1,2}$

\section{Author contributions}

D. Lebeaux: drafting/revising the manuscript, data acquisition, study concept or design, analysis or interpretation of data, accepts responsibility for conduct of research and final approval, acquisition of data. I. Klein: analysis or interpretation of data, accepts responsibility for conduct

\section{MORE ONLINE}

\section{$\rightarrow$ Teaching slides}

links.lww.com/WNL/

A892

From Centre d'Infectiologie Necker-Pasteur and Institut Imagine (D.L., O.L.), Hôpital Necker Enfants Malades, Assistance Publique-Hôpitaux de Paris, Sorbonne Paris Cité, Université Paris Descartes; Neuroimaging Department (I.K.), Clinic Alleray-Labrouste, Paris; Department of Diagnostic Radiology (G.G.), Gustave Roussy, Villejuif; and Critical Care Unit, Department of Neurology, and Stroke Center (F.P.), Versailles Saint Quentin en Yvelines University, Versailles Hospital, France. D.L. is currently affiliated with the Hôpital Européen Georges Pompidou, Unité Mobile de Microbiologie Clinique, Service de Microbiologie, AP-HP, Sorbonne Paris Cité, Université Paris Descartes, France.

Go to Neurology.org/N for full disclosures. Funding information and disclosures deemed relevant by the authors, if any, are provided at the end of the article. 
of research and final approval, acquisition of data. G. Garcia: $\mathrm{drafting} /$ revising the manuscript, analysis or interpretation of data, accepts responsibility for conduct of research and final approval, acquisition of data. F. Bruneel: drafting/revising the manuscript, accepts responsibility for conduct of research and final approval. F. Pico: data acquisition, study concept or design, analysis or interpretation of data, accepts responsibility for conduct of research and final approval, acquisition of data, study supervision. O. Lortholary: drafting/ revising the manuscript, data acquisition, study concept or design, accepts responsibility for conduct of research and final approval, acquisition of data, study supervision.

\section{Study funding}

No targeted funding reported.

\section{Disclosure}

The authors report no disclosures relevant to the manuscript. Go to Neurology.org/N for full disclosures.

\section{References}

1. Marzolf G, Sabou M, Lannes B, et al. Magnetic resonance imaging of cerebral aspergillosis: imaging and pathological correlations. PLoS One 2016;11:e0152475.

2. Norlinah MI, Ngow HA, Hamidon BB. Angioinvasive cerebral aspergillosis presenting as acute ischaemic stroke in a patient with diabetes mellitus. Singapore Med J 2007;48: e1-e4. 


\section{Neurology}

Teaching NeuroImages: Aspergillosis-induced vasculitis presenting as ischemic stroke
in an immunocompetent patient

David Lebeaux, Isabelle Klein, Gabriel Garcia, et al.

Neurology 2019;92;e2618-e2619

DOI 10.1212/WNL.0000000000007575

This information is current as of May 27, 2019

\section{Updated Information \&} Services

References

Subspecialty Collections

Permissions \& Licensing

Reprints including high resolution figures, can be found at: http://n.neurology.org/content/92/22/e2618.full

This article cites 2 articles, 0 of which you can access for free at: http://n.neurology.org/content/92/22/e2618.full\#ref-list-1

This article, along with others on similar topics, appears in the following collection(s):

Fungal infections

http://n.neurology.org/cgi/collection/fungal_infections Infarction

http://n.neurology.org/cgi/collection/infarction

MRI

http://n.neurology.org/cgi/collection/mri

Information about reproducing this article in parts (figures,tables) or in its entirety can be found online at:

http://www.neurology.org/about/about_the_journal\#permissions

Information about ordering reprints can be found online:

http://n.neurology.org/subscribers/advertise

Neurology ${ }^{\circledR}$ is the official journal of the American Academy of Neurology. Published continuously since 1951, it is now a weekly with 48 issues per year. Copyright @ 2019 American Academy of Neurology. All rights reserved. Print ISSN: 0028-3878. Online ISSN: 1526-632X.

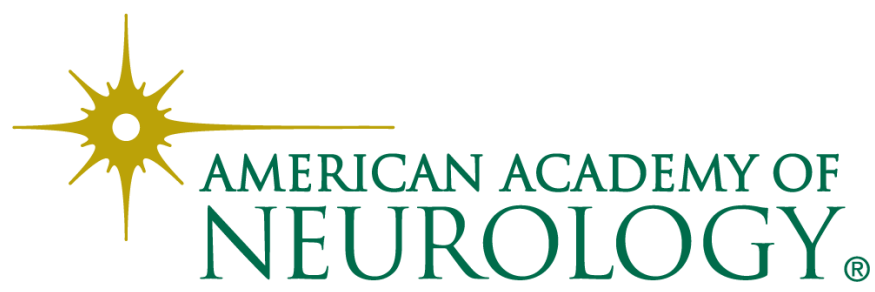

